\title{
Laccase-catalyzed derivatization of 6-aminopenicillanic, 7-aminocephalosporanic and 7-aminodesacetoxycephalosporanic acid
}

\author{
Annett Mikolasch ${ }^{1^{*}}$ (D) Elke Hammer ${ }^{2}$, Sabine Witt ${ }^{3}$ and Ulrike Lindequist ${ }^{4}$
}

\begin{abstract}
Trametes spec. laccase (EC 1.10.3.2.) mediates the oxidative coupling of 6-aminopenicillanic, 7-aminocephalosporanic, and 7-aminodesacetoxycephalosporanic acid with 2,5-dihydroxybenzoic acid derivatives to form new penicillin and cephalosporin structures, respectively. The heteromolecular hybrid dimers are formed by nuclear amination of the $p$-hydroquinones with the primary amines and inhibited in vitro the growth of Staphylococcus species, including some multidrug-resistant strains.
\end{abstract}

Keywords: Laccase, Biotransformation, B-lactam antibiotics, Antibacterial activity

\section{Key points}

Fungal laccase catalyzes the coupling of 2,5-dihydroxybenzoic acid derivatives with the core units of penicillins and cephalosporins.

In contrast to the inactive educts the coupling products possess weak to moderate antibacterial activity.

Chinoid substructures impact antimicrobial spectrum and activity.

\section{Introduction}

The laccase-mediated reaction is a well-described method to synthesize novel antibiotics by enzymatic catalysis (Agematu et al. 1993; Anyanwutaku et al. 1994; Mikolasch et al. 2016; Zhang et al. 2020). These reactions enable the use of low-cost processes, mild reaction conditions-aqueous solvent systems, normal pressure, room temperature - to synthesize novel antibiotics. A further advantage is the specificity of the laccase-initiated reaction, which catalyse the amination and thiolation of para- and ortho-dihydroxylated aromatic compounds (Abdel-Mohsen et al. 2014; Manda et al.

\footnotetext{
*Correspondence: annett.mikolasch@uni-greifswald.de

${ }^{1}$ Institute of Microbiology, University Greifswald, Felix-Hausdorff-Straße 8,

Greifswald 17489, Germany

Full list of author information is available at the end of the article
}

2005; Niedermeyer et al. 2005; Patel and Gupte 2018; Schlippert et al. 2016; Wellington et al. 2013). Further examples of useful modifications are laccase-mediated reactions in which two antibiotics containing a phenol moiety are combined (Agematu et al. 1993), or where a phenolic compound is added into an antibiotic containing a phenolic moiety (Anyanwutaku et al. 1994), or the synthesis or transformation of heterocyclic compounds (Mikolasch and Schauer 2003; Saadati et al. 2018; Schäfer et al. 2001; Youssef et al. 2020).

Recently we reviewed the laccase-mediated synthesis of novel antibiotics (Mikolasch 2019). Several of the reported products inhibited the growth of gram positive bacterial strains and protected mice against severe disease after infection with Staphylococcus aureus (Mikolasch et al. 2008, 2012, 2016). In all of our work so far, we have focused on the transformation of existing approved ß-lactam antibiotics. However, many bacteria, including clinically significant Staphylococcus and Streptococcus species, have developed resistance to these antibiotics so that novel antibiotic structures are urgently needed to replace them (Blinder et al. 2019; Fisher et al. 2005; Helfand and Bonomo 2005; Mbaye et al. 2019; Shimizu et al. 2001).

Therefore, in this study we used the core structural elements of $ß$-lactam antibiotics, the 6-aminopenicillanic, 
7-aminocephalosporanic, and 7-aminodesacetoxycephalosporanic acid, as coupling partners for laccase-mediated reactions. The aim was to change the C- 6 and C-7 substituent respectively, as has been previously achieved (Dabernat et al. 2004; Lam et al. 2015; Lin et al. 2003; Lopez et al. 2004; Potron et al. 2013; Springer et al. 2003; Stachulski 1985), but by using a novel synthesis approach.

We have employed laccase $C$ from Trametes spec. to achieve derivatization of the core structures of $\beta$-lactam antibiotics and to couple them with 2,5-dihydroxy-N(2-hydroxyethyl)benzamide and 2,5-dihydroxybenzoic acid methyl ester. These 2,5-dihydroxybenzoic acid derivatives are structurally related to the ganomycins, another class of antibacterial compounds (Mothana et al. 2000). The novel heteromolecular hybrid dimers were characterized by LC/MS and NMR data and the antimicrobial activity assayed in an agar diffusion and a cytotoxicity test.

\section{Materials and methods Enzyme}

Extracellular laccase $\mathrm{C}$ of Trametes spec. (EC 1.10.3.2) was obtained from ASA Spezialenzyme (Wolfenbüttel, Germany) and used in an activity of $800 \mathrm{nmol} \cdot \mathrm{mL}^{-1} \cdot \mathrm{min}^{-1}$ (substrate: 2,2'-amino-bis-3-ethylbenzthiazoline-6-sulfonic acid).

\section{Substrates and conditions of biotransformation}

6-Aminopenicillanic, 7-aminocephalosporanic and 7-aminodesacetoxycephalosporanic acid $(2 \mathrm{mM})$ were dissolved in $600 \mathrm{ml}$ sodium acetate buffer, $20 \mathrm{mM}$ $\mathrm{pH}$ 5.6. After addition of laccase $\mathrm{C}$ (activity 800 $\left.\mathrm{nmol} \cdot \mathrm{mL}^{-1} \cdot \mathrm{min}^{-1}\right)$, 2,5-dihydroxybenzoic acid derivatives-2,5-dihydroxy-N-(2-hydroxyethyl)benzamide or 2,5-dihydroxybenzoic acid methyl ester - were added $(60 \mathrm{ml}$ of a $20 \mathrm{mM}$ solution in sodium acetate buffer, $\mathrm{pH}$ 5.6). The reaction mixture was incubated for $3 \mathrm{~h}$ at room temperature (RT) with agitation at $400 \mathrm{rpm}$.

Chemicals were purchased from commercial suppliers: 2,5-dihydroxybenzoic acid methyl ester, 6-aminopenicillanic, 7-aminocephalosporanic and 7-aminodesacetoxycephalosporanic acid from Sigma-Aldich (Germany) and 2,5-dihydroxy-N-(2-hydroxyethyl)benzamide from Midori Kagaku Co (Japan).

\section{Analytical high-performance liquid chromatography (HPLC) and general procedure for isolation of biotransfor- mation products}

For routine analysis, samples of the incubation mixture were analyzed by HPLC and use of substrates and product synthesis recorded by a UV detector. The isolation of the coupling products was performed by solid phase extraction. Methods were described in detail by Mikolasch et al. (2006).

\section{Characterization of biotransformation products}

Products were analyzed by mass spectrometry (LC/MS with API-ES in negative and positive modes) and FT-ICR MS high-resolution mass spectrometry experiments as described by Manda et al. (2006). The nuclear magnetic resonance (NMR) spectra were obtained at $300 \mathrm{MHz}$ $\left({ }^{1} \mathrm{H}\right)$ in acetonitrile- $\mathrm{d}_{3}$.

\section{7-[[2-(2-Hydroxyethylcarbamoyl)-3,6-dioxocy- clohexa-1,4-dien-1-yl]amino]-penicillanic acid $3 a$} Yield $66 \%,{ }^{1} \mathrm{H}$ NMR $\delta 1.50$ (s, 3H, H-9 or H-10), 1.56 (s, $3 \mathrm{H}, \mathrm{H}-9$ or $\mathrm{H}-10), 3.39\left(\mathrm{~m},{ }^{3} \mathrm{~J}=5.5 \mathrm{~Hz}, 2 \mathrm{H}, \mathrm{H}-9^{\prime}\right), 3.59$ $\left(\mathrm{t},{ }^{3} \mathrm{~J}=5.5 \mathrm{~Hz}, 2 \mathrm{H}, \mathrm{H}-10^{\prime}\right), 4.44(\mathrm{~s}, 1 \mathrm{H}, \mathrm{H}-3), 5.64\left(\mathrm{dd},{ }^{3} \mathrm{~J}\right.$ $=4.0 \mathrm{~Hz}, 1 \mathrm{H}, \mathrm{H}-5), 5.72\left(\mathrm{~d},{ }^{3} \mathrm{~J}=4.0 \mathrm{~Hz}, 1 \mathrm{H}, \mathrm{H}-6\right), 6.63(\mathrm{~d}$, $\left.{ }^{3} \mathrm{~J}=10.3 \mathrm{~Hz}, 1 \mathrm{H}, \mathrm{H}-4^{\prime}\right), 6.71\left(\mathrm{~d},{ }^{3} \mathrm{~J}=10.3 \mathrm{~Hz}, 1 \mathrm{H}, \mathrm{H}-5^{\prime}\right)$, 9.67 (s(broad), 1H, H-8'), 12.99 (s(broad), 1H, H-11). LC/MS $m / z 408.0$ ([M-H] $]^{-}$API-ES neg. mode), 410.3 $\left([\mathrm{M}+\mathrm{H}]^{+}\right.$API-ES pos. mode), HRMS $\left(\mathrm{C}_{17} \mathrm{H}_{19} \mathrm{~N}_{3} \mathrm{O}_{7} \mathrm{~S}\right)$ : calcd: 409.09437, found: 409.09441.

\section{7-[(2-Methoxycarbonyl-3,6-dioxocyclohexa-1,4-dien-1-yl) amino]-penicillanic acid $3 b$}

Yield 66\%, ${ }^{1} \mathrm{H}$ NMR $\delta 1.52$ (s, 3H, H-9 or H-10), 1.55 (s, $3 \mathrm{H}, \mathrm{H}-9$ or H-10), 3.80 (s, 3H, H-8'), 3.95 (s, 1H, H-3), $5.52\left(\mathrm{~m},{ }^{3} \mathrm{~J}=4.0 \mathrm{~Hz}, 1 \mathrm{H}, \mathrm{H}-5\right), 5.63\left(\mathrm{~d},{ }^{3} \mathrm{~J}=4.0 \mathrm{~Hz}, 1 \mathrm{H}\right.$, $\mathrm{H}-6), 6.63\left(\mathrm{~d},{ }^{3} \mathrm{~J}=10.1 \mathrm{~Hz}, 1 \mathrm{H}, \mathrm{H}-4^{\prime}\right), 6.71\left(\mathrm{~d},{ }^{3} \mathrm{~J}=\right.$ $\left.10.1 \mathrm{~Hz}, 1 \mathrm{H}, \mathrm{H}-5^{\prime}\right), 11.59$ (s(broad), 1H, H-11), LC/MS $m / z 379.2\left([\mathrm{M}-\mathrm{H}]^{-}\right.$API-ES neg. mode), $381.3\left([\mathrm{M}+\mathrm{H}]^{+}\right.$ API-ES pos. mode), HRMS $\left(\mathrm{C}_{16} \mathrm{H}_{16} \mathrm{~N}_{2} \mathrm{O}_{7} \mathrm{~S}\right)$ : calcd: 380.06782 , found: 380.06789 .

\section{3-(Acetoxymethyl)-7-[[2-(2-hydroxyethylcarbamoyl)-3,6-di-} oxocyclohexa-1,4-dien-1-yl]amino]-cephalosporanic acid 3c Yield 68\%, ${ }^{1} \mathrm{H}$ NMR $\delta 2.01(\mathrm{~s}, 3 \mathrm{H}, \mathrm{H}-12), 3.41\left(\mathrm{~d},{ }^{2} \mathrm{~J}=\right.$ $18.3 \mathrm{~Hz}, 1 \mathrm{H}, \mathrm{H}-2), 3.40\left(\mathrm{~m},{ }^{3} \mathrm{~J}=5.5 \mathrm{~Hz}, 2 \mathrm{H}, \mathrm{H}-9^{\prime}\right), 3.59(\mathrm{t}$, $\left.{ }^{3} \mathrm{~J}=5.5 \mathrm{~Hz}, 2 \mathrm{H}, \mathrm{H}-10^{\prime}\right), 3.64\left(\mathrm{~d},{ }^{2} \mathrm{~J}=18.3 \mathrm{~Hz}, 1 \mathrm{H}, \mathrm{H}-2\right)$, $4.77\left(\mathrm{~d},{ }^{2} \mathrm{~J}=13.2 \mathrm{~Hz}, 1 \mathrm{H}, \mathrm{H}-10\right), 5.05\left(\mathrm{~d},{ }^{2} \mathrm{~J}=13.2 \mathrm{~Hz}\right.$, $1 \mathrm{H}, \mathrm{H}-10), 5.26\left(\mathrm{~d},{ }^{3} \mathrm{~J}=4.7 \mathrm{~Hz}, 1 \mathrm{H}, \mathrm{H}-6\right), 5.79\left(\mathrm{~m},{ }^{3} \mathrm{~J}=\right.$ $4.7 \mathrm{~Hz}, 1 \mathrm{H}, \mathrm{H}-7), 6.66\left(\mathrm{~d},{ }^{3} \mathrm{~J}=10.3 \mathrm{~Hz}, 1 \mathrm{H}, \mathrm{H}-4^{\prime}\right), 6.72(\mathrm{~d}$, $\left.{ }^{3} \mathrm{~J}=10.3 \mathrm{~Hz}, 1 \mathrm{H}, \mathrm{H}-5^{\prime}\right), 9.64$ (s(broad), $\left.1 \mathrm{H}, \mathrm{H}-8^{\prime}\right), 12.96$ (s(broad), 1H, H-13). LC/MS $m / z 464.0\left([\mathrm{M}-\mathrm{H}]^{-}\right.$API-ES neg. mode), $466.2\left([\mathrm{M}+\mathrm{H}]^{+}, 488.1[\mathrm{M}+\mathrm{Na}]^{+}\right.$API-ES pos. mode), HRMS $\left(\mathrm{C}_{19} \mathrm{H}_{19} \mathrm{~N}_{3} \mathrm{O}_{9} \mathrm{~S}\right)$ : calcd: 465.08420, found: 465.08431 .

\section{3-(Acetoxymethyl)-7-[(2-methoxycarbonyl-3,6-dioxocy- clohexa-1,4-dien-1-yl)amino]-cephalosporanic acid 3d} Yield $63 \%,{ }^{1} \mathrm{H}$ NMR $\delta 2.00(\mathrm{~s}, 3 \mathrm{H}, \mathrm{H}-12), 3.30\left(\mathrm{~d},{ }^{2} \mathrm{~J}=\right.$ $18.0 \mathrm{~Hz}, 1 \mathrm{H}, \mathrm{H}-2), 3.59$ (d, $\left.{ }^{2} \mathrm{~J}=18.0 \mathrm{~Hz}, 1 \mathrm{H}, \mathrm{H}-2\right), 3.81$ (s, 3H, H-8'), 4.81 (d, $\left.{ }^{2} \mathrm{~J}=12.9 \mathrm{~Hz}, 1 \mathrm{H}, \mathrm{H}-10\right), 5.05$ (d, 
$\left.{ }^{2} \mathrm{~J}=12.9 \mathrm{~Hz}, 1 \mathrm{H}, \mathrm{H}-10\right), 5.13\left(\mathrm{~d},{ }^{3} \mathrm{~J}=4.1 \mathrm{~Hz}, 1 \mathrm{H}, \mathrm{H}-6\right)$, $5.47\left(\mathrm{~m},{ }^{3} \mathrm{~J}=4.1 \mathrm{~Hz}, 1 \mathrm{H}, \mathrm{H}-7\right), 6.64\left(\mathrm{~d},{ }^{3} \mathrm{~J}=10.2 \mathrm{~Hz}, 1 \mathrm{H}\right.$, H-4 $\left.{ }^{\prime}\right), 6.72\left(\mathrm{~d},{ }^{3} \mathrm{~J}=10.2 \mathrm{~Hz}, 1 \mathrm{H}, \mathrm{H}-5^{\prime}\right), 11.65$ (s(broad), 1H, H-13). LC/MS $m / z 434.9\left([\mathrm{M}-\mathrm{H}]^{-}\right.$API-ES neg. mode), $437.2\left([\mathrm{M}+\mathrm{H}]^{+}\right.$API-ES pos. mode), HRMS $\left(\mathrm{C}_{18} \mathrm{H}_{16} \mathrm{~N}_{2} \mathrm{O}_{9} \mathrm{~S}\right)$ : calcd: 436.05765 , found: 436.05778 .

\section{7-[[2-(2-Hydroxyethylcarbamoyl)-3,6-dioxocy-} clohexa-1,4-dien-1-yl]amino]-desacetoxy-cephalosporanic acid $3 e$

Yield 73\%, Synthesis and isolation as described above. Dark red solid. ${ }^{1} \mathrm{H}$ NMR $\delta 2.09$ (s, 3H, H-10), 3.24 (d, $\left.{ }^{2} \mathrm{~J}=18.1 \mathrm{~Hz}, 1 \mathrm{H}, \mathrm{H}-2\right), 3.40\left(\mathrm{~m},{ }^{3} \mathrm{~J}=5.5 \mathrm{~Hz}, 2 \mathrm{H}, \mathrm{H}-9^{\prime}\right)$, $3.59\left(\mathrm{~d},{ }^{2} \mathrm{~J}=18.1 \mathrm{~Hz}, 1 \mathrm{H}, \mathrm{H}-2\right), 3.60\left(\mathrm{t},{ }^{3} \mathrm{~J}=5.5 \mathrm{~Hz}, 2 \mathrm{H}\right.$, $\left.\mathrm{H}-10^{\prime}\right), 5.21\left(\mathrm{~d},{ }^{3} \mathrm{~J}=4.6 \mathrm{~Hz}, 1 \mathrm{H}, \mathrm{H}-6\right), 5.72\left(\mathrm{dd},{ }^{3} \mathrm{~J}=\right.$ $4.6 \mathrm{~Hz}, \mathrm{~J}=5.6 \mathrm{~Hz}, 1 \mathrm{H}, \mathrm{H}-7), 6.66\left(\mathrm{~d},{ }^{3} \mathrm{~J}=10.2 \mathrm{~Hz}, 1 \mathrm{H}\right.$, H-4'), 6.72 (d, $\left.{ }^{3} \mathrm{~J}=10.1 \mathrm{~Hz}, 1 \mathrm{H}, \mathrm{H}-5^{\prime}\right), 9.65$ (s(broad), $1 \mathrm{H}, \mathrm{H}-8^{\prime}$ ), 12.95 (s(broad), 1H, H-11). LC/MS $\mathrm{m} / z 406.0$ $\left([\mathrm{M}-\mathrm{H}]^{-}\right.$API-ES neg. mode), $408.2\left([\mathrm{M}+\mathrm{H}]^{+}, 430.1\right.$ $[\mathrm{M}+\mathrm{Na}]^{+}$API-ES pos. mode), HRMS $\left(\mathrm{C}_{17} \mathrm{H}_{17} \mathrm{~N}_{3} \mathrm{O}_{7} \mathrm{~S}\right)$ : calcd: 407.07872, found: 407.07881.

\section{7-[(2-Methoxycarbonyl-3,6-dioxocyclohexa-1,4-dien-1-yl) amino]-desacetoxy-cephalosporanic acid $3 f$}

Yield 71\%, ${ }^{1} \mathrm{H}$ NMR $\delta 2.07$ (s, 3H, H-10), $3.22\left(\mathrm{~d},{ }^{2} \mathrm{~J}=\right.$ $17.9 \mathrm{~Hz}, 1 \mathrm{H}, \mathrm{H}-2), 3.53$ (d, $\left.{ }^{2} \mathrm{~J}=17.9 \mathrm{~Hz}, 1 \mathrm{H}, \mathrm{H}-2\right), 3.81$ (s, 3H, H-8'), 5.11 (d, $\left.{ }^{3} \mathrm{~J}=3.9 \mathrm{~Hz}, 1 \mathrm{H}, \mathrm{H}-6\right), 5.46\left(\mathrm{~m},{ }^{3} \mathrm{~J}=\right.$ $3.9 \mathrm{~Hz}, 1 \mathrm{H}, \mathrm{H}-7), 6.63$ (d, $\left.{ }^{3} \mathrm{~J}=10.2 \mathrm{~Hz}, 1 \mathrm{H}, \mathrm{H}-4^{\prime}\right), 6.72$ $\left(\mathrm{d},{ }^{3} \mathrm{~J}=10.2 \mathrm{~Hz}, 1 \mathrm{H}, \mathrm{H}-5^{\prime}\right), 10.15$ (s(broad), 1H, H-11). LC/MS $m / z 377.2$ ([M-H $]^{-}$API-ES neg. mode), 379.2 $\left([\mathrm{M}+\mathrm{H}]^{+}\right.$API-ES pos. mode), HRMS $\left(\mathrm{C}_{16} \mathrm{H}_{14} \mathrm{~N}_{2} \mathrm{O}_{7} \mathrm{~S}\right)$ : calcd: 378.05217, found: 378.05225.

\section{Determination of antibacterial activity}

An agar diffusion method described previously was used to determine antibacterial activity in the range from 19 to $190 \mathrm{nmol}$ (Mikolasch et al. 2007). The following bacterial strains were used: Staphylococcus aureus ATCC 6538, S. aureus Norddeutscher Epidemiestamm and the multidrug resistant strains isolated from patients S. aureus 315 and $S$. epidermidis 99,847 .

\section{Cytotoxic activity}

Cytotoxicity was determined by a neutral red uptake assay using FL-cells, a human amniotic epithelial cell line, as reported before (Mikolasch et al. 2007).

\section{Results}

Biotransformation of 6-aminopenicillanic acid by laccase Laccase-mediated reactions of 2,5-dihydroxy-N-(2-hydroxyethyl)benzamide 1a and 2,5-dihydroxybenzoic acid methyl ester 1b with 6-aminopenicillanic acid $\mathbf{2 a}$ both resulted in one heteromolecular hybrid dimer each, $\mathbf{3 a}$ and $\mathbf{3 b}$ (Fig. 1).

After separation of $\mathbf{3} \mathbf{a}$ and $\mathbf{3 b}$ by solid phase extraction, LC/MS in negative and positive mode and HRMS analyses revealed molecular masses of the products attributed to the formation of heteromolecular hybrid dimers consisting of a structural part of a 2,5-dihydroxybenzoic acid derivative (1a or $\mathbf{1 b}$ ) coupled to 6-aminopenicillanic acid 2a accompanied by the loss of four hydrogen atoms. These couplings were confirmed by the presence of characteristic signals for $\mathbf{1 a}$ or $\mathbf{1 b}$ and for $\mathbf{2 a}$ in the ${ }^{1} \mathrm{H}$ NMR spectra of $\mathbf{3 a}$ and $\mathbf{3 b}$. The number of $\mathrm{CH}$ proton signals of the 2,5-dihydroxybenzoic acid derivatives changed from three in the substrate, to two signals in the products. The multiplicity of the proton signals $\mathrm{H}-4$ ' and $\mathrm{H}-5$ ' indicated an additional substituent at the $\mathrm{C}-1^{\prime}$ atom and the loss of a proton. The chemical shift to lower field of the $\mathrm{H}-4$ ' and $\mathrm{H}-5$ " signals confirmed the presence of an electronwithdrawing group. Signals for phenolic hydroxyl groups could not be measured, but instead additional amine protons were detected. All analytical data confirmed the oxidation of the $p$-hydroquinone structure of $\mathbf{1 a}$ and $\mathbf{1 b}$ to a quinone.<smiles>[R]C(=O)c1cc(O)ccc1O</smiles>

$1 a, 1 b$
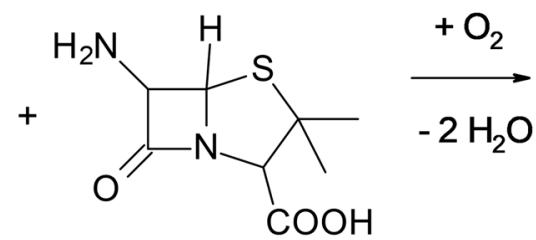

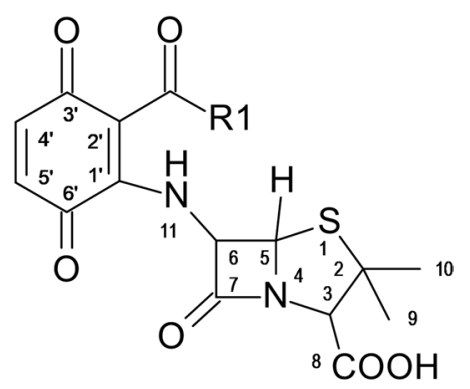

3a, 3b

Fig. 1 2,5-Dihydroxybenzoic acid derivatives $\left(\mathbf{1} \mathbf{a} \mathrm{R} 1=\mathrm{NH}\left(\mathrm{CH}_{2}\right)_{2} \mathrm{OH}\right.$ and $\left.\mathbf{1 b} \mathrm{R} 1=\mathrm{OOCH} \mathrm{H}_{3}\right), 6$-aminopenicillanic acid (2a) and the products $\mathbf{3 a}$ $\left(\mathrm{R} 1=\mathrm{NH}\left(\mathrm{CH}_{2}\right)_{2} \mathrm{OH}\right)$ and $\mathbf{3 b}\left(\mathrm{R} 1=\mathrm{OOCH}_{3}\right)$ 
The heteromolecular hybrid dimers $\mathbf{3 a}$ and $\mathbf{3} \mathbf{b}$ are formed by nuclear amination of the $p$-hydroquinones 1a or $\mathbf{1 b}$ with the primary amino group of $\mathbf{2 a}$ (Fig. 2).

\section{Biotransformation of 7-aminocephalosporanic and 7-ami-} nodesacetoxycephalosporanic acid by laccase

7-Aminocephalosporanic $\mathbf{2 b}$ and 7-aminodesacetoxycephalosporanic acid $2 \mathbf{c}$ reacted in the same way as 6-aminopenicillanic acid 2a with 2,5-dihydroxy-N-(2-hydroxyethyl)benzamide $\mathbf{1 a}$ and 2,5-dihydroxybenzoic acid methyl ester $\mathbf{1 b}$ under the presence of laccase. A heteromolecular hybrid dimer, 3c, 3d, 3e or 3f, was recoved from each reaction (Fig. 3).

The extraction by solid phase and the structural analysis by LC/MS, HRMS and NMR of products $\mathbf{3 c}$ to $\mathbf{3 f}$ gave comparable results to the products $\mathbf{3 a}$ and $\mathbf{3 b}$. The reactions are expected to follow the same mechanism.

\section{Biological activity of the biotransformation products}

The products 3a to $3 \mathbf{f}$ caused low to moderate growth inhibition of $S$. aureus and S. epidermidis strains, among them multidrug resistant staphylococci (Table 1). In contrast, the educts $\mathbf{1 a}$ and $\mathbf{1 b}$ and $\mathbf{2 a}$ to $\mathbf{2} \mathbf{c}$ were not active against the strains tested. This indicates that by laccasemediated reaction a product with antimicrobial activity can be produced from two initially inactive compounds. The previously described products $\mathbf{3 A}, \mathbf{3 B}$ and $3 \mathrm{C}$ (Mikolasch et al. 2006, 2007) were built from inactive 2,5-dihydroxybenzoic acid derivatives $\mathbf{1 a}$ or $\mathbf{1 b}$ and from the clinically relevant antibiotics amoxicillin or cefadroxil. The antibiotic activity of $\mathbf{3 A}, \mathbf{3 B}$, and $\mathbf{3 C}$ was comparable to that of the educts amoxicillin and cefadroxil.

Good product stability was demonstrated by HPLC measurement when the compounds were stored in solid form at $4{ }^{\circ} \mathrm{C}$ for several weeks. However, incubation of the compounds $\mathbf{3 a}$ to $\mathbf{3 f}$ in aqueous solutions at<smiles>[R17]C(=O)c1cc(O)ccc1O</smiles><smiles>[R2]C(=O)c1cc(O)ccc1O</smiles>

$1 a, 1 b$<smiles>[R2]C(=O)C1=C(NC2=C(C(=O)O)N3CS[C@H]2C(C(=O)O)=C([R2])C3=O)C(=O)C=CC1=O</smiles>

$3 c, 3 d, 3 e, 3 f$

Fig. 3 2,5-Dihydroxybenzoic acid derivatives $\left(\mathbf{1} \mathbf{a} \mathrm{R} 1=\mathrm{NH}\left(\mathrm{CH}_{2}\right)_{2} \mathrm{OH}\right.$ and $\left.\mathbf{1 b} \mathrm{R} 1=\mathrm{COOCH}_{3}\right)$, 7-aminocephalosporanic acid $\left(\mathbf{2} \mathbf{b} \mathrm{R} 2=\mathrm{CH}_{2} \mathrm{OCOCH}\right)$, 7-aminodesacetoxy-cephalosporanic acid $\left(\mathbf{2} \mathbf{c} 2=\mathrm{CH}_{3}\right)$ and the products $\mathbf{3 c}\left(\mathrm{R} 1=\mathrm{NH}\left(\mathrm{CH}_{2}\right)_{2} \mathrm{OH}, \mathrm{R} 2=\mathrm{CH}_{2} \mathrm{OCOCH}_{3}\right), \mathbf{3} \mathbf{d}\left(\mathrm{R} 1=\mathrm{COOCH}_{3}\right.$, $\left.\mathrm{R} 2=\mathrm{CH}_{2} \mathrm{OCOCH}_{3}\right), \mathbf{3 e}\left(\mathrm{R} 1=\mathrm{NH}\left(\mathrm{CH}_{2}\right)_{2} \mathrm{OH}, \mathrm{R} 2=\mathrm{CH}_{3}\right)$ and $\mathbf{3 f}\left(\mathrm{R} 1=\mathrm{COOCH}_{3}, \mathrm{R} 2=\mathrm{CH}_{3}\right)$ 
Table 1 Antimicrobial activity of products $3 a$ to $3 f$, educts $2 a$ to $2 c$ and comparable data from previous research (educts $2 A$ to $2 C$ and products $3 A$ to $3 C$ )

\begin{tabular}{|c|c|c|c|c|c|c|c|c|c|c|c|c|c|c|c|}
\hline \multirow[t]{3}{*}{ Strain } & \multicolumn{15}{|c|}{ Amount $\mathrm{n}$ [ $\mathrm{\mu mol}]$} \\
\hline & \multicolumn{3}{|l|}{$2 a$} & \multicolumn{3}{|l|}{$3 a$} & \multicolumn{3}{|l|}{$3 \mathbf{b}$} & \multicolumn{3}{|c|}{$2 A(A M)^{c}$} & \multicolumn{3}{|c|}{$3 A(1 a+A M)^{c}$} \\
\hline & 0.019 & 0.1 & 0.19 & 0.019 & 0.1 & 0.19 & 0.019 & 0.1 & 0.19 & 0.019 & 0.1 & 0.19 & 0.019 & 0.1 & 0.19 \\
\hline Staphylococcus aureus ATCC 6538 & $r^{a}$ & r & r & $12^{b}$ & 18 & 22 & r & 24 & 30 & 36 & 42 & 44 & 26 & 30 & 34 \\
\hline S. aureus Norddeutscher Stamm & r & r & r & r & 16 & 18 & r & r & 16 & r & 12 & 14 & r & 10 & 14 \\
\hline S. aureus 315 & r & r & r & r & r & r & r & r & $r$ & 8 & 14 & 16 & r & 8 & 12 \\
\hline S. epidermidis 99,847 & $r$ & $r$ & $r$ & r & $r$ & r & $r$ & $r$ & $r$ & 20 & 24 & 26 & 14 & 20 & 22 \\
\hline \multirow[t]{3}{*}{ Strain } & \multicolumn{15}{|c|}{ Amount $n$ [ $\mu$ mol] } \\
\hline & \multicolumn{3}{|l|}{$\mathbf{2 b}$} & \multicolumn{3}{|l|}{$3 c$} & \multicolumn{3}{|l|}{$3 d$} & \multicolumn{3}{|c|}{$2 B(C D)^{d}$} & \multicolumn{3}{|c|}{$3 B(1 a+C D)^{d}$} \\
\hline & 0.019 & 0.1 & 0.19 & 0.019 & 0.1 & 0.19 & 0.019 & 0.1 & 0.19 & 0.019 & 0.1 & 0.19 & 0.019 & 0.1 & 0.19 \\
\hline S. aureus ATCC 6538 & r & r & r & r & 14 & 18 & r & r & 10 & 32 & 38 & 40 & 20 & 28 & 30 \\
\hline S. aureus Norddeutscher Stamm & $r$ & r & r & r & 20 & 24 & r & r & $r$ & $r$ & r & 10 & r & 16 & 18 \\
\hline S. aureus 315 & r & r & r & r & r & r & r & r & r & r & r & 8 & r & 10 & 16 \\
\hline S. epidermidis 99,847 & r & r & r & r & r & 22 & r & r & 14 & 20 & 24 & 26 & r & 10 & 16 \\
\hline \multirow[t]{3}{*}{ Strain } & \multicolumn{15}{|c|}{ Amount $n$ [ $\mu$ mol] } \\
\hline & \multicolumn{3}{|l|}{$2 c$} & \multicolumn{3}{|l|}{$3 e$} & \multicolumn{3}{|l|}{$3 f$} & \multicolumn{3}{|c|}{$2 B(C D)^{d}$} & \multicolumn{3}{|c|}{$3 C(1 b+C D)^{d}$} \\
\hline & 0.019 & 0.1 & 0.19 & 0.019 & 0.1 & 0.19 & 0.019 & 0.1 & 0.19 & 0.019 & 0.1 & 0.19 & 0.019 & 0.1 & 0.19 \\
\hline S. aureus ATCC 6538 & r & r & r & r & 18 & 22 & r & 14 & 30 & 32 & 38 & 40 & 18 & 26 & 30 \\
\hline S. aureus Norddeutscher Stamm & r & r & r & r & 20 & 22 & r & r & r & r & r & 10 & r & 10 & 14 \\
\hline S. aureus 315 & r & r & r & r & $r$ & $r$ & r & r & $r$ & $r$ & r & 8 & $r$ & r & 12 \\
\hline S. epidermidis 99,847 & r & r & r & r & r & 24 & r & r & r & 20 & 24 & 26 & r & 14 & 20 \\
\hline \multicolumn{16}{|l|}{ a Resistant (no zone of inhibition) } \\
\hline \multicolumn{16}{|l|}{ b Zones of inhibition (mm) } \\
\hline \multicolumn{16}{|c|}{ c Educt 2A and product 3A are described previously (Mikolasch et al. 2006); AM amoxicillin } \\
\hline d Educt $\mathbf{2 B}$ and products $\mathbf{3 B}, \mathbf{3 C}$ are & escribed & reviou & sly (Miko & lasch et a & 2007) & $C D$ cefa & oxil & & & & & & & & \\
\hline
\end{tabular}

$30{ }^{\circ} \mathrm{C}$ resulted in decomposition within three hours. For this reason, the survey of the antimicrobial effects was restricted to agar diffusion tests.

3a to $3 f$ showed no cytotoxicity against FL cells in concentrations up to $100 \mu \mathrm{g} / \mathrm{ml}$ (data not shown).

\section{Discussion}

With the use of laccase $\mathrm{C}$ from Trametes spec., the laccase substrates 1a and 1b were consumed rapidly, resulting in high yields of the cross coupling product $\mathbf{3 a}$ to $\mathbf{3} \mathbf{f}$. Similar straightforward biotransformations of educts to products were described for hybrid dimer formation from the laccase substrates 1a and $\mathbf{1 b}$ (para-dihydroxylated) with aminopenicillins, aminocephalosporins, and aminocarbacephems (Mikolasch et al. 2006, 2007).

In contrast, divergent reaction kinetics were observed for hybrid dimer formation from syringic acid (monohydroxylated and meta-dimethoxylated) and 3,4-dichloroaniline (Tatsumi et al. 1994) or from 3,4-dihydroxyaromatic acid substructures (ortho-dihydroxylated) and ß-lactam antibiotics (Mikolasch et al. 2012). Therefore, the laccase-mediated reaction of $\mathbf{1 a}$ and $\mathbf{1 b}$ with 6-aminopenicillanic 2a, 7-aminocephalosporanic $\mathbf{2 b}$, and 7 -aminodesacetoxycephalosporanic acid 2c again confirmed that para-dihydroxylated laccase substrates are preferable reaction partners in these syntheses in comparison to ortho-substituted compounds.

The structural analyses indicate that the products $\mathbf{3 a}$ to $3 \mathbf{f}$ are quinoids formed by Michael addition (Fig. 2). Despite this structural equivalence to the products described in other studies ( $3 \mathrm{~A}$ to $3 \mathrm{C}$, Table 1), there was only a comparatively low antibacterial activity against Staphylococcus strains (Table 1). Amoxicillin (2A, AM, Table 1), an $\alpha$-amino-p-hydroxybenzyl penicillin with a structure similar to $\mathbf{3 a}$ and $\mathbf{3 b}$, is a semisynthetic derivative of penicillin but with better absorption and higher concentrations in blood and in urine. It is recommended for treatment of acute otitis media (Handsfield et al. 1973; Zimmermann and Peterson 2006). Cefadroxil (2B, CD, Table 1), an 
$\alpha$-amino-p-hydroxybenzyl cephalosporin with a structure similar to $\mathbf{3 e}$ and $\mathbf{3 f}$, is a derivative of cephalosporin effective in Gram-positive and Gram-negative bacterial infections (Beauduy and Winston 2018; de Marco and Salgado 2017). Both AM and CD have a hydroxylated aromatic ring within the structure attached at the 6- or 7 -position of the $\beta$-lactam basic structure, while products $3 \mathbf{a}, 3 \mathbf{b}, \mathbf{3 e}$, and $3 \mathbf{f}$ contain a quinoid ring directly attached to these positions. These structural differences could result in a low shielding of the B-lactam structure. The $\beta$-lactam structures are analogues of $\mathrm{d}$-alanyl-d-alanine, the terminal amino acid residues on the precursor NAM/NAG-peptide subunits of the nascent peptidoglycan layer. The $\beta$-lactam nuclei irreversibly bind to the active site of bacterial transpeptidases involved in peptidoglycan synthesis. Therefore, they act as inhibitors of the cross-linkage between the linear peptidoglycan polymer chains and disrupt the cell wall synthesis (Fisher et al. 2005). If the bacteria produce $\beta$-lactamases, these enzymes cleave the $\beta$-lactam ring and reduce the antibiotic effect (Drawz and Bonomo 2010). In case of less well-shielded $\beta$-lactam nuclei, the antibiotics might be susceptible to bacterial degradation and thereby less active as documented for $\mathbf{3 a}$ to $\mathbf{3} \mathbf{f}$. However, these products were built from two inactive substances by laccase-mediation. In contrast, the previously described products $\mathbf{3 A}, \mathbf{3 B}$ and $\mathbf{3 C}$ produced from an antibiotic $A M$ or $C D$ and from an inactive 2,5-dihydroxybenzoic acid derivative only had comparable antibiotic activity to the educts $\mathrm{AM}$ or $\mathrm{CD}$.

The structures of 3a to $\mathbf{3 f}$ include a $p$-quinoid unit. Several compounds with $p$-quinone clusters are important chemotherapeutics with cytostatic activity (Ikushima et al. 1980; Nweze et al. 2020; Pachatouridis et al. 2002; Whitesell et al. 1992). Therefore, it is remarkable that 3a to 3f did not show a cytotoxic effect on FL cells, though effects on eukaryotic cells can differ, as reported for geldanamycin, a $p$-benzoquinone antitumor antibiotic (Whitesell et al. 1992). No cytotoxic effect on FL cells was also observed for the previously described products $\mathbf{3 A}, \mathbf{3 B}$, and $\mathbf{3 C}$ that also include a $p$-quinoid unit. (Mikolasch et al. 2006, 2007).

With the present study we demonstrate that two inactive educts can be linked together by laccase-mediation to form an active heteromolecular product at high yield. However, the impact of product substructures on antimicrobial activity and bacterial sensitivity have to be tested more intensively in order to exploit the whole potential of the chinoid products $\mathbf{3 a}$ to $\mathbf{3 f}$ as well as $\mathbf{3 A}$, 3B, and $\mathbf{3 C}$.

\section{Acknowledgements}

We thank R. Jack (Prof. Emeritus, Institute of Immunology, University of Greifswald) for help in preparing the manuscript.

\section{Authors' contributions}

AM, EH and UL conceived and designed research. AM, EH and SW conducted experiments. AM and SW analyzed data. AM wrote the manuscript. We thank M. Kindermann, S. Siegert and B. Witt for NMR data acquisition, and S. Sokolowski for LC/MS data acquisition. All authors read and approved the final manuscript.

\section{Funding}

Open Access funding enabled and organized by Projekt DEAL. This study was not funded.

\section{Ethics approval and consent to participate}

This article does not contain any studies with human participants or animals performed by any of the authors.

\section{Competing interests}

Author Annett Mikolasch declares that she has no conflict of interest. Author Elke Hammer declares she has no conflict of interest. Author Sabine Witt declares that she has no conflict of interest. Author Ulrike Lindequist declares that she has no conflict of interest.

\section{Author details}

${ }^{1}$ Institute of Microbiology, University Greifswald, Felix-Hausdorff-Straße 8, Greifswald 17489, Germany. ${ }^{2}$ Interfaculty Institute for Genetics and Functional Genomics, University Greifswald, Felix-Hausdorff-Straße 8, Greifswald 17489, Germany. ${ }^{3}$ Biometec, Walther-Rathenau-Str. 49a, Greifswald 17489, Germany. ${ }^{4}$ Institute of Pharmacy University Greifswald, Friedrich-Ludwig-Jahn-Str. 17, Greifswald 17487, Germany.

Received: 12 August 2020 Accepted: 24 September 2020

Published online: 02 October 2020

\section{References}

Abdel-Mohsen HT, Conrad J, Beifuss U (2014) Laccase-catalyzed synthesis of catechol thioethers by reaction of catechols with thiols using air as an oxidant. Green Chem 16(1):90-95. https://doi.org/10.1039/c3gc41968a

Agematu H, Tsuchida T, Kominato K, Shibamoto N, Yoshioka T, Nishida H, Okamoto R, Shin T, Murao S (1993) Enzymatic dimerization of penicillin X. J Antibiot 46(1):141-148. https://doi.org/10.7164/antibiotics.46.141

Anyanwutaku I, Petroski R, Rosazza J (1994) Oxidative coupling of mithramycin and hydroquinone catalyzed by copper oxidases and benzoquinone. Implications for the mechanism of action of aureolic acid antibiotics. Biorg Med Chem 2:543-551

Beauduy CE, Winston LG (2018) Beta-lactam and other cell wall- and membrane-active antibiotics. In: Katzung BG (ed) Basic pharmacology and clinical, 14th edn. McGraw-Hill Education, New York City, pp 795-814

Blinder OO, Blinder OV, Rotar DV, Humenna AV (2019) Antibiotic resistance peculiarities of $\mathrm{S}$ aureus isolates, obtained from nasal and throat mucosa of outpatients\&nbsp;Chernivtsi city. Zaporozhye Med J 2:240-245. https ://doi.org/10.14739/2310-1210.2019.2.161504

Dabernat H, Seguy A, Faucon G, Delmas C (2004) Epidemiology of Haemophilus influenzae strains identified in 2001 in France, and assessment of their susceptibility to beta-lactams. Med Mal Infect 34(2):97-101 https://doi. org/10.1016/j.medmal.2003.10.005

de Marco BA, Salgado HRN (2017) Characteristics, properties and analytical methods of cefadroxil: a review. Crit Rev Anal Chem 47(2):93-98. https:// doi.org/10.1080/10408347.2016.1219649

Drawz SM, Bonomo RA (2010) Three decades of beta-lactamase Inhibitors. Clin Microbiol Rev 23(1):160-160+. https://doi.org/10.1128/cmr.00037-09

Fisher JF, Meroueh SO, Mobashery S (2005) Bacterial resistance to beta-lactam antibiotics: Compelling opportunism, compelling opportunity. Chem Rev 105(2):395-424. https://doi.org/10.1021/cr030102i

Handsfield HH, Clark H, Wallace JF, Holmes KK, Turck M (1973) Amoxicillin, a new penicillin antibiotic. Antimicrob Agents Chemother 3(2):262-265. https://doi.org/10.1128/aac.3.2.262

Helfand MS, Bonomo RA (2005) Current challenges in antimicrobial chemotherapy: The impact of extended-spectrum beta-lactamases and metallo-beta-lactamases on the treatment of resistant Gram-negative 
pathogens. Curr Opin Pharm 5(5):452-458. https://doi.org/10.1016/j. coph.2005.04.013

Ikushima H, Okamoto M, Tanaka H, Ohe O, Kohsaka M, Aoki H, Imanaka H (1980) New anticoccidial antibiotics, WS-5995 A and B. I. Isolation and characterization. J Antibiot 33(10):1107-1113. https://doi.org/10.7164/ antibiotics.33.1107

Lam TT, Claus H, Elias J, Frosch M, Vogel U (2015) Ampicillin resistance of invasive Haemophilus influenzae isolates in Germany 2009-2012. Int J Med Microbiol 305(7):748-755. https://doi.org/10.1016/j.ijmm.2015.08.028

Lin WP, Ji DD, Shiau CY, Yang TC, Yang YW, Tsou TL, Tang ST, Chen CH, Liu YT (2003) In vitro and in vivo antipseudomonal activity, acute toxicity, and mode of action of a newly synthesized fluoroquinolonyl ampicillin derivative. J Lab Clin Med 142(3):158-165. https://doi.org/10.1016/s0022 $-2143(03) 00112-4$

Lopez MA, Rodriguez Z, Gonzalez M, Tolon B, Avila R, Gonzalez I, Garmendia L, Mamposo T, Carrasco R, Pellon R, Velez H, Fini A (2004) Novel cephalosporin derivatives possessing a substituted cinnamoyl moiety at the 7 beta-position. Synthesis, structural characterization and antibacterial activity of 3-acetoxymethyl cephalosporin derivatives. Eur J Med Chem 39(8):657-664. https://doi.org/10.1016/j.ejmech.2004.02.016

Manda K, Hammer E, Mikolasch A, Niedermeyer T, Dec J, Jones AD, Benesi AJ, Schauer F, Bollag JM (2005) Laccase-induced cross-coupling of 4-aminobenzoic acid with para-dihydroxylated compounds 2,5-dihydroxy-N(2-hydroxyethyl)-benzamide and 2,5-dihydroxybenzoic acid methyl ester. J Mol Catalysis B-Enzymatic 35(4-6):86-92. https://doi.org/10.1016/j. molcatb.2005.06.001

Manda K, Hammer E, Mikolasch A, Gordes D, Thurow K, Schauer F (2006) Laccaseinduced derivatization of unprotected amino acid L-tryptophan by coupling with p-hydroquinone 2,5-dihydroxy-N-(2-hydroxyethyl)-benzamide. Amino Acids 31 (4):409-419. https://doi.org/10.1007/s00726-005-0276-8

Mbaye MN, Gilis D, Rooman M (2019) Rational antibiotic design: in silico structural comparison of the functional cavities of penicillin-binding proteins and B-lactamases. J Biomol Struct Dyn 37(1):65-74. https://doi. org/10.1080/07391102.2017.1418678

Mikolasch A, Schauer F (2003) Biotransformation of N-(2-alkylamino-4-phenylimidazol-1-yl)-acetamides and kinetic studies by using cells and laccase from Trametes versicolor. J Basic Microbiol 43(6):508-521. https:// doi.org/10.1002/jobm.200310280

Mikolasch A, Niedermeyer T, Lalk M, Witt S, Seefeldt S, Hammer E, Schauer F, Gesell M, Hessel S, Juelich WD, Lindequist U (2006) Novel penicillins synthesized by biotransformation using laccase from Trametes spec. Chem Pharm Bull\&nbsp: 54(5):632-638. https://doi.org/10.1248/cpb.54.632

Mikolasch A, Niedermeyer T, Lalk M, Witt S, Seefeldt S, Hammer E, Schauer F, Gesell Salazar M, Hessel S, Juelich WD, Lindequist U (2007) Novel cephalosporins synthesized by amination of 2,5-dihydroxybenzoic acid derivatives using fungal laccases II. Chem Pharm Bull\&nbsp; 55(3):412-416. https://doi.org/10.1248/cpb.55.412

Mikolasch A, Wurster M, Lalk M, Witt S, Seefeldt S, Hammer E, Schauer F, Juelich WD, Lindequist U (2008) Novel beta-lactam antibiotics synthesized by amination of catechols using fungal laccase. Chem Pharm Bull\&nbsp; 56(7):902-907. https://doi.org/10.1248/cpb.56.902

Mikolasch A, Manda K, Schlueter R, Lalk M, Witt S, Seefeldt S, Hammer E, Schauer F, Juelich WD, Lindequist U (2012) Comparative analyses of laccase-catalyzed amination reactions for production of novel betalactam antibiotics. Biotechnol Appl Biochem 59(4):295-306. https://doi. org/10.1002/bab.1026

Mikolasch A, Hildebrandt O, Schluter R, Hammer E, Witt S, Lindequist U (2016) Targeted synthesis of novel beta-lactam antibiotics by laccase-catalyzed reaction of aromatic substrates selected by pre-testing for their antimicrobial and cytotoxic activity. Appl Microbiol Biotechnol 100(11):48854899. https://doi.org/10.1007/s00253-016-7288-z

Mikolasch A (2019) Laccase-mediated synthesis of novel antibiotics and amino acid derivatives. In: Grunwald P (ed) Pharmaceutical Biocatalysis: Chemoenzymatic Synthesis of Active Pharmaceutical Ingredients. Jenny Stanford Publishing Singapore, pp 219-268

Mothana RAA, Jansen R, Julich WD, Lindequist U (2000) Ganomycins A and $B$, new antimicrobial farnesyl hydroquinones from the basidiomycete Ganoderma pfeifferi. J Nat Prod 63(3):416-418. https://doi.org/10.1021/ np990381y

Niedermeyer THJ, Mikolasch A, Lalk M (2005) Nuclear amination catalyzed by fungal laccases: Reaction products of $p$-hydroquinones and primary aromatic amines. J Org Chem 70(6):2002-2008. https://doi.org/10.1021/ jo048454s

Nweze JA, Mbaoji FN, Huang G, Li YM, Yang LY, Zhang YK, Huang SS, Pan LX, Yang DF (2020) Antibiotics development and the potentials of marinederived compounds to stem the tide of multidrug-resistant pathogenic bacteria, fungi, and protozoa. Mar Drugs. https://doi.org/10.3390/md180 30145

Pachatouridis C, lakovidou Z, Myoglou E, Mourelatos D, Pantazaki AA, Papageorgiou VP, Kotsis A, Liakopoulou-Kyriakides M (2002) Synthesis and cytogenetic effects of aminoquinone derivatives with a di- and a tripeptide. Anticancer Drugs 13(4):367-372. https://doi.org/10.1097/00001 813-200204000-00005

Patel H, Gupte A (2018) Laccase catalysis: A green approach in bioactive compound synthesis Research advancements in pharmaceutical, nutritional, and industrial enzymology. Advances in medical technologies and clinical practice, pp 178-212

Potron A, Rondinaud E, Poirel L, Belmonte O, Boyer S, Camiade S, Nordmann P (2013) Genetic and biochemical characterisation of OXA-232, a carbapenem-hydrolysing class $D$ beta-lactamase from Enterobacteriaceae. Int J Antimicrob Agents 41(4):325-329. https://doi.org/10.1016/j.ijantimica g.2012.11.007

Saadati S, Ghorashi N, Rostami A, Kobarfard F (2018) Laccase-based oxidative catalytic systems for the aerobic aromatization of tetrahydroquinazolines and related $\mathrm{N}$-heterocyclic compounds under mild conditions. Eur J Org Chem 2018(30):4050-4057. https://doi.org/10.1002/ejoc.201800466

Schäfer A, Specht M, Hetzheim A, Francke W, Schauer F (2001) Synthesis of substituted imidazoles and dimerization products using cells and laccase from Trametes versicolor. Tetrahedron 57(36):7693-7699. https://doi. org/10.1016/s0040-4020(01)00751-7

Schlippert M, Mikolasch A, Hahn V, Schauer F (2016) Enzymatic thiol Michael addition using laccases: Multiple C-S bond formation between $\mathrm{p}$-hydroquinones and aromatic thiols. J Mol Catalysis B-Enzymatic 126:106-114. https://doi.org/10.1016/..molcatb.2015.12.012

Shimizu M, Shiota S, Mizushima T, Ito H, Hatano T, Yoshida T, Tsuchiya T (2001) Marked potentiation of activity of beta-lactams against methicillin-resistant Staphylococcus aureus by corilagin. Antimicrob Agents Chemother 45(11):3198-3201. https://doi.org/10.1128/aac.45.11.3198-3201.2001

Springer DM, Luh BY, Goodrich J, Bronson JJ (2003) Anti-MRSA cephems. part 2: C-7 cinnamic acid derivatives. Biorg Med Chem 11(2):265-279. https:// doi.org/10.1016/s0968-0896(02)00336-x

Stachulski AV (1985) Penicillin C-6 substitution - a novel oxygen-bridged dimer. Tetrahedron Lett 26(15):1883-1884. https://doi.org/10.1016/s0040 $-4039(00) 94764-6$

Tatsumi K, Freyer A, Minard RD, Bollag JM (1994) Enzyme-mediated coupling of 3,4-dichloroanilin and ferulic acid: a model for pollutant binding to humic materials. Environ Sci Technol 28(2):210-215. https://doi. org/10.1021/es00051a005

Wellington KW, Gordon GER, Ndlovu LA, Steenkamp P (2013) Laccase-catalyzed C-S and C-C coupling for a one-pot synthesis of 1,4-naphthoquinone sulfides and 1,4-naphthoquinone sulfide dimers. Chemcatchem 5(6):1570-1577. https://doi.org/10.1002/cctc.201200606

Whitesell L, Shifrin SD, Schwab G, Neckers LM (1992) Benzoquinonoid ansamycins possess selective tumoricidal activity unrelated to src kinase inhibition. Cancer Res 52(7):1721-1728

Youssef ASA, Hemdan MM, Azab ME, Emara SA, Elsayed GA, Kamel RM (2020) Syringaldehyde as a scaffold for the synthesis of some biologically potent heterocycles. J Heterocycl Chem 57(3):1133-1142. https://doi. org/10.1002/jhet.3850

Zhang YY, Sun YJ, Ren WJ, Zhao QX, Lv KY, Tang H, Gao X, Yang FK, Wang FY, Liu JH (2020) Synthesis of mitomycin analogs catalyzed by coupling of laccase with lipase and the kinetic model. J Chem Technol Biotechnol 95(5):1421-1430. https://doi.org/10.1002/jctb.6327

Zimmermann L, Peterson AM (2006) Otitis media and otitis externa. In: Arcangelo VP, Peterson AM (eds) Pharmacotherapeutics for advanced practice: a practical approach, 2nd edn. Lippincott Williams and Wilkins, Philadelphia, pp 183-193

\section{Publisher's Note}

Springer Nature remains neutral with regard to jurisdictional claims in published maps and institutional affiliations. 